\title{
Effects of Collagen Grafting on Cell Behaviors in BCP Scaffold with Interconnected Pore Structure
}

Dong-Jun Yang ${ }^{1}$, Jae-Hui Jeon², Sun-Young Lee', Hyun-Wook An¹, Keun Oh Park', Kwang-Bum Park' and Sukyoung $\mathrm{Kim}^{2 *}$

\begin{abstract}
Background: This study was to investigate the effect of collagen grafted porous biphasic calcium phosphate (BCP) on cell attachment, proliferation, and differentiation. Porous BCP scaffolds with interconnected micropore structure were prepared with were prepared and then grafted with a collagen type I. The hydroxyapatite (HA) and $\beta$ tricalcium phosphate (TCP) ratio of the TCP scaffolds was about 60/40 and the collagen was crosslinked on the TCP scaffold surface (collagen-TCP).

Results: The sintered BCP scaffolds showed fully interconnected micropore structures with submicron-sized grains. The collagen crosslinking in the scaffolds was conducted using the the N-(3-Dimethylaminopropyl)-N '-ethylcarbodiimide hydrochloride and N-hydroxysuccinimide (NHS) crosslinking method. The cell proliferation of collagen-BCP scaffolds showed a similar result to that of the BCP scaffolds. However, osteoblastic differentiation and cell attachment increased in the collagen-BCP scaffolds.
\end{abstract}

Conclusions: Collagen-BCP scaffold improved the cell attachment ability in early phase and osteoblastic differentiation.

Keywords: Hydroxyapatite (HA), Tricalcium phosphate (TCP), Biphasic calcium phosphate (BCP), Collagen

\section{Background}

Autograft, xenograft, and synthetic grafting bone substitutes with diverse chemical compositions are widely used as an alternative to autogenous grafting material to repair osseous defects in dentistry [1-5]. The calcium phosphate such as hydroxyapatite (HA), $\beta$-tricalcium phosphate $(\beta-\mathrm{TCP})$ and biphasic calcium phosphate (BCP) are commonly used as a bone substitute due to their excellent biocompatibility. The most synthetic BCP bone substitute consists of a mixture of HA and $\beta$-TCP with various ratio. HA and $\beta$-TCP are very different in terms of the solubility or dissolution rate, which reflects their bioreactivity. $\beta$-TCP resorbs more quickly than HA [6]. Therefore, the bioreactivity of BCP can be controlled by changing the ratio of $\mathrm{HA}$ and $\beta$-TCP [7].

\footnotetext{
* Correspondence: sykim@ynu.ac.kr

${ }^{2}$ School of Materials Science \& Engineering, Yeungnam University,

Gyeongsan, Gyeongbuk 712-749, Korea

Full list of author information is available at the end of the article
}

The structural characteristics and chemical composition of BCP scaffolds play a critical role in osteoconductivity of bone substitute. In structural aspects, the pore size at both macro- and micro-levels, porosity and the interconnection of microspores are important factors for bone healing [8-13]. In recent study, donut shape $\mathrm{BCP}$ bone substitutes made of a central macro-pore (about $300 \sim 400 \mu \mathrm{m}$ ) and micro-pores (about 20-60 $\mu \mathrm{m}$ ) showed greater new bone formation when compared with similar BCP composition with micro-pores [14]. In general, $\mathrm{BCP}$ with various $\mathrm{HA} / \mathrm{TCP}$ ratio shows greater new bone formation when compared with HA and $\beta$-TCP.

Collagen which is one of extracellular components of bone tissue promotes osteogenic differentiation of osteoblast and mesenchymal stem cells in vitro [15-18]. It is known that HA functionalized with collagen I affects the cell adhesion and mineralization of mesenchymal stem cells [19]. And collagen-TCP porous ceramics are used 
in human extraction socket healing and forms sufficient amounts of vital bone [20].

This study aimed to investigate the cell behaviors such as cell attachment, proliferation, and differentiation in porous BCP ceramics. Especially, the effect of collagen crosslinked on BCP ceramic surface was examined. In order to compare the cell behaviors between pure BCP and collagen grafted $\mathrm{BCP}$ ceramics (collagen-BCP) with interconnected micropore structures, collagen-BCP samples were prepared by crosslinking the N-(3-Dimethylaminopropyl)- $\mathrm{N}^{\prime}$-ethylcarbodiimide hydrochloride and $\mathrm{N}$-hydroxysuccinimide (NHS) on pure BCP ceramics. It is known that the compound of EDC and NHS is a coupling agent and efficient and non-toxic crosslinking material [21-23].

\section{Methods}

\section{Preparation of BCP scaffolds}

BCP powder was synthesized by a precipitation method using $14.17 \mathrm{~g}$ of $\mathrm{Ca}$ (NO3)2"4H2O (Duksan Pure Chemicals; Gyunggi-do, Korea) and 5.11 g of $\left(\mathrm{NH}_{4}\right)_{2}{ }_{2}{ }^{\prime \prime} \mathrm{HPO}_{4}$ (Duksan Pure Chemicals; Gyunggi-do, Korea). First, Ca $\left(\mathrm{NO}_{3}\right)_{2} " 4 \mathrm{H}_{2} \mathrm{O}$ and $\left(\mathrm{NH}_{4}\right)_{2}{ }_{2} \mathrm{HPO}_{4}$ were dissolved in distilled water and $\left(\mathrm{NH}_{4}\right)_{2}{ }_{2} \mathrm{HPO}_{4}$ solution was added drop by drop to the $\mathrm{Ca}\left(\mathrm{NO}_{3}\right)_{2}{ }_{2} 4 \mathrm{H}_{2} \mathrm{O}$ solution. The $\mathrm{pH}$ of the solution was adjusted to 8.5 with ammonium hydroxide (Duksan) after dissolved completely at $80{ }^{\circ} \mathrm{C}$. And the solution was stirred for $1 \mathrm{~h}$, washed with distilled water to remove ammonium hydroxide and filtered with $0.2 \mu \mathrm{m}$ membrane filter. The filter cake was crushed and dried in a drying oven for $12 \mathrm{~h}$. The asdried powder was then calcined at $900{ }^{\circ} \mathrm{C}$ for $1 \mathrm{~h}$. The donut shape porous BCP samples were produced with the calcined powder.

\section{Collagen crosslinking}

The collagen on the BCP scaffold surface was chemically crosslinked. First, $5 \%$ collagen was dispersed in $1 \%$ acetic acid at $0 \sim-5{ }^{\circ} \mathrm{C}$ for $6 \sim 12 \mathrm{~h}$. A mixture of 0.05 g N-(3-dimethylaminopropyl)-N'-ethylcarbodiimide hydrochloride (EDC, Sigma-Aldrich Canada, Ltd; Oakville, Canada) and $0.05 \mathrm{~g}$ N-hydroxysuccinimide (NHS, Sigma-Aldrich Canada, Ltd; Oakville, Canada) was prepared in distilled water as described previously [21-23]. Carbodiimide crosslinking in collagen solution by using EDC and NHS was performed by reacting the two solutions at $0 \sim-5{ }^{\circ} \mathrm{C}$ for $24 \mathrm{~h}$ in ice bath. In order to crosslink the collagen on BCP surface, the BCP scaffolds were immersed in $10 \%$ 3-aminopropyltriethoxysilane (3APTES) at $95{ }^{\circ} \mathrm{C}$ for $2 \mathrm{~h}$, washed three times with distilled water and dried in a drying oven. The crosslinking of amino group on the scaffold surface was performed via the 3-APTES terminal amino group. The 3-APTES treated BCP scaffolds with amino groups reacted with the prepared collagen solution at room temperature for $6 \mathrm{~h}$. Collagen treated BCP samples (collagen-TCP) were washed three times with distilled water and dried.

\section{X-ray diffraction (XRD)}

Both BCP scaffolds before and after collagen crosslinking (TCP and collagen-TCP) were analyzed to examine the crystalline phases (HA and TCP) with X-ray diffractometer (DMAX-2500, RIGAKU, Japan). The diffractometer was operated at $40 \mathrm{kV}$ and $30 \mathrm{~mA}$ employing a step size of $1 \% \mathrm{~min}$.

\section{Scanning electron microscopy (SEM)}

Surface morphology of both scaffolds was observed using scanning electron microscope (SEM) equipped with energy dispersive X-spectroscope (EDS) (Hitachi S4200, Tokyo, Japan). Accelerating voltage was set as $15 \mathrm{kV}$.

\section{X-ray photoelectron spectroscopy}

In order to confirm the collagen crosslinked on BCP surface, X-ray photoelectron spectroscopy (XPS, Quantera SXM, ULVAC-PHI, Japan) was used.

\section{Coomassie brilliant blue staining}

Scaffolds were stained in $0.1 \%$ Coomassie brilliant blue R250 for 20 min and destined in $45 \%$ methanol and $10 \%$ glacial acetic acid until the background of the gel was removed.

\section{Cell attachment}

The MC3T3-E1 cells $\left(2 \times 10^{4}\right.$ cells $)$, a mouse calvariaderived osteoblast-like cell line, and implants in $\alpha$ modified Eagle's medium ( $\alpha$-MEM) were repeatedly rotated by using a rotation plate $(2 \mathrm{rpm})$ in a flat-bottom tube at $37{ }^{\circ} \mathrm{C}$ for $3 \mathrm{~h}$ [24]. The cells on three samples

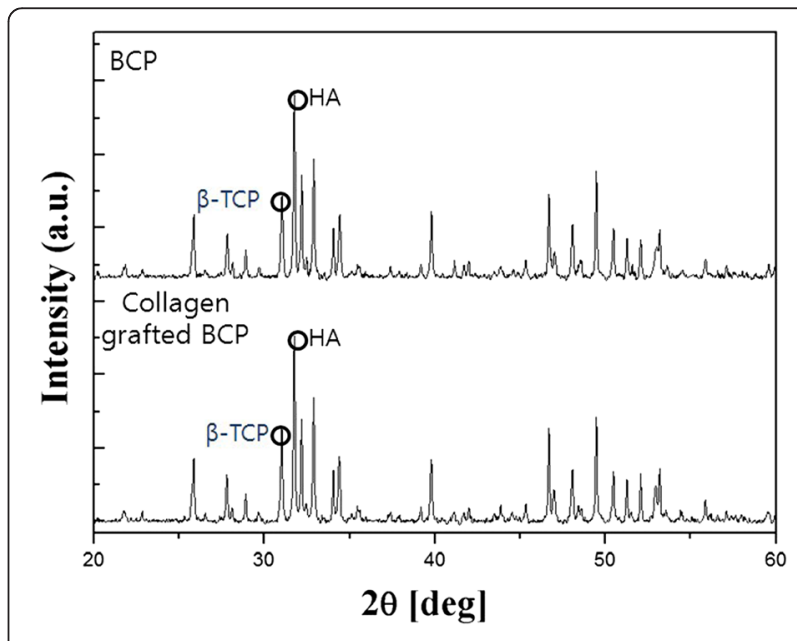

Fig. 1 X-ray diffraction of BCP scaffolds and collagen/ BCP scaffolds 


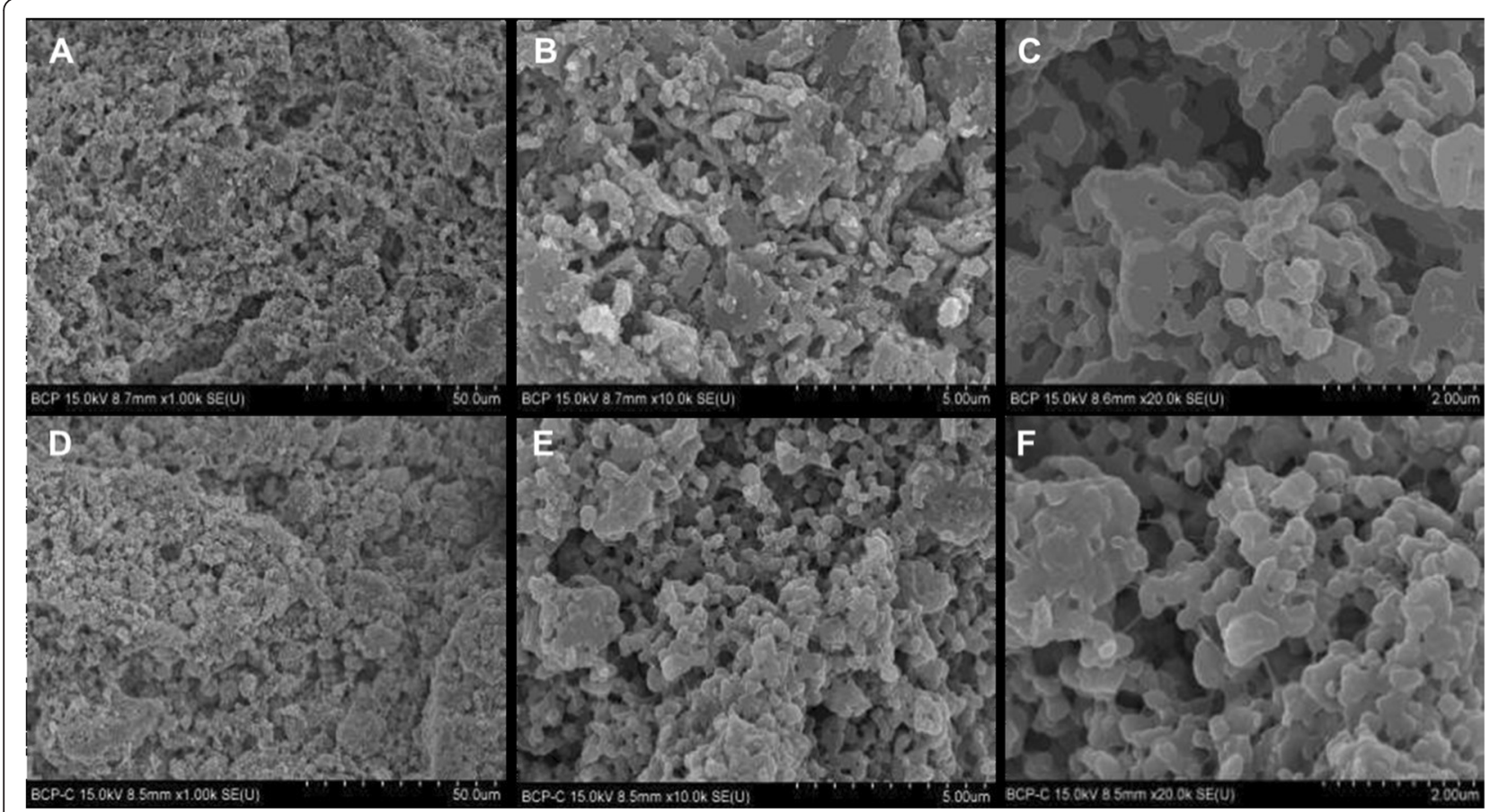

Fig. 2 Scanning electron microscope image of BCP scaffolds and collagen/ BCP scaffolds. SEM images of BCP scaffolds (a, b, c) and collagen/ BCP scaffolds (d, e, f) at magnifications of $\times 1000(\mathbf{a}, \mathbf{d}), \times 10000(\mathbf{b}, \mathbf{e})$ and $\times 20000(\mathbf{c}, \mathbf{f})$

(control HA, pure $\mathrm{BCP}$ and collagen-BCP) were incubated in a $5 \% \mathrm{CO}_{2}$ incubator at $37{ }^{\circ} \mathrm{C}$ for $3 \mathrm{~h}$. After incubation, the scaffolds were washed twice with phosphate buffered saline (pH 7.4). Fixation was carried out for $30 \mathrm{~min}$ in $2 \%$ glutaraldehyde. The scaffold samples were then washed twice with $0.1 \mathrm{M}$ sodium cacodylate buffer $(\mathrm{pH} 7.4)$, dehydrated sequentially in $25 \%$, $50 \%, 75 \%, 95 \%$, and $100 \%$ ethanol, for 5 min each, and dried with tetramethylsilane. The scaffold specimens were coated with gold, examined, and photographed using a SEM equipped with an EDS (SEM/EDS, S-4800, Hitachi, Tokyo, Japan).

\section{Cell proliferation}

The MC3T3-E1 cells were seeded into 24-well plates at a density of $2 \times 10^{4}$ cells per well. After $24 \mathrm{~h}$, control, pure BCP and collagen-BCP scaffolds were added into each well. The cells on three samples were incubated in a $5 \% \mathrm{CO}_{2}$ incubator at $37^{\circ} \mathrm{C}$ for 1,4 and 7 days. MTT (3-(4,5-dimethylthiazol-2yl)-2,5-diphenyl tetrazolium

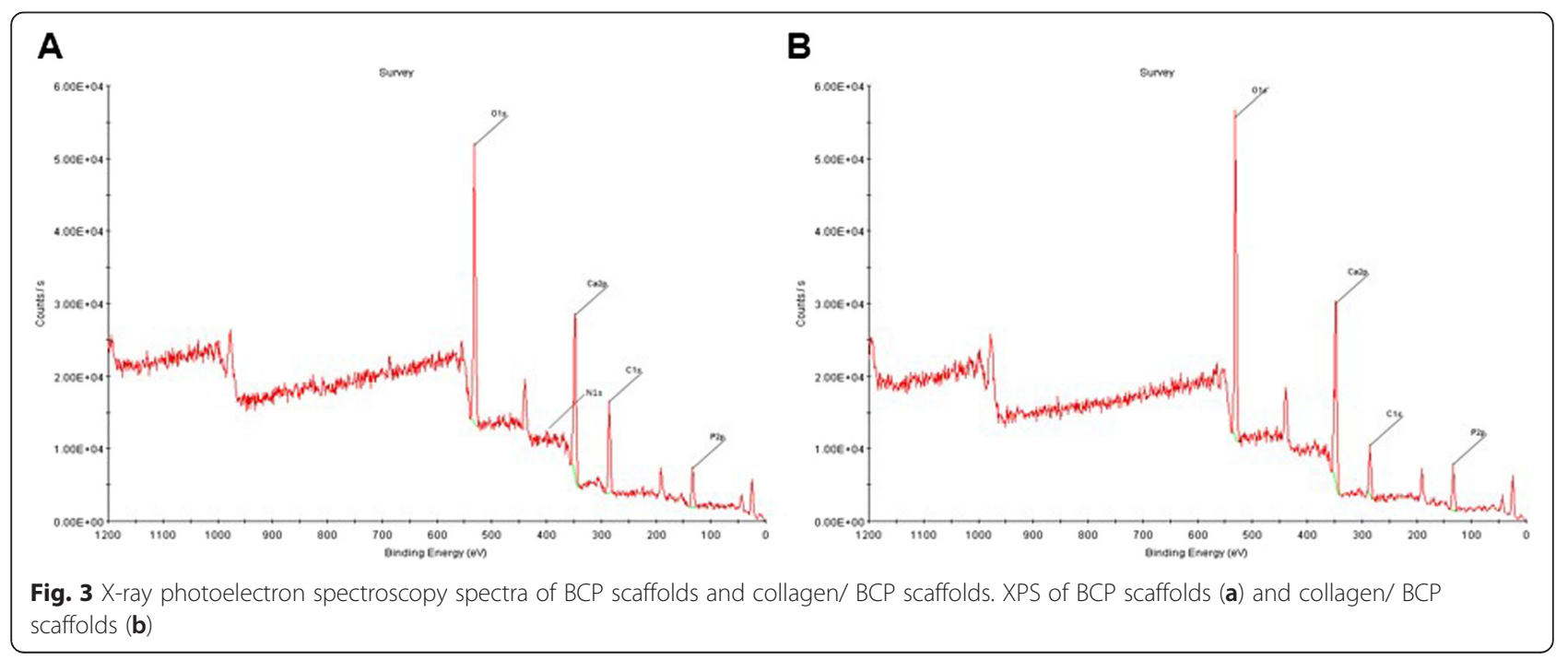




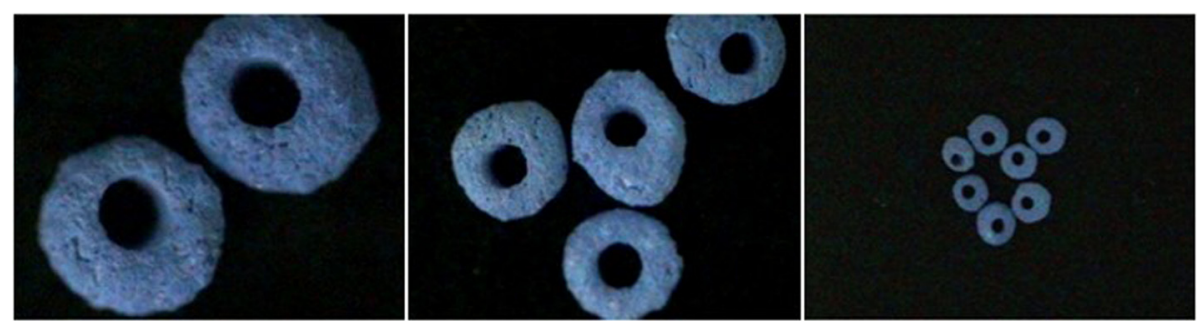

Fig. 4 Coomassie brilliant blue staining of collagen/ BCP scaffolds

bromide) assay was performed for the cell proliferation at 1,4 , and 7 days. $0.5 \mathrm{mg} / \mathrm{ml}$ of MTT solution was added to each well. After $3 \mathrm{~h}$, the MTT solution was aspirated and the dimethylsulfoxide was added to solubilize the formed formazan. The optical density was measured at a wavelength of $570 \mathrm{~nm}$ using an ELISA reader (PowerWave XS, Bio-Tek, Winooski, USA). Cell counting was performed for the cell quantification for 3, 5 , and 7 days. The cells were detached from culture plate, and washed with PBS. The cells were counted by using a haemocyotometer.

\section{Alkaline phosphate (ALP) staining}

The MC3T3-E1 cells were seeded into 24-well plates at a density of $2 \times 10^{4}$ cells per well. After $24 \mathrm{~h}$, the media was changed with osteogenic medium and then pure $\mathrm{BCP}$ and collagen-BCP scaffolds were added into each well. The cells were incubated at $37{ }^{\circ} \mathrm{C}$ in a humidified atmosphere of $5 \% \mathrm{CO}_{2}$ for 7 days. The cells were washed PBS and the ALP staining was performed using alkaline phosphatase (ALP) Kit (SIGMA-ALDRICH, INC; St. Louis, MO, USA).

\section{Statistical analysis}

Statistical analysis was performed by a using SPSS 11.0 statistical system (SPSS Inc., Chicago, IL, USA). The paired Student $t$-test was performed to compare the significance of the differences in cell proliferation. Values of $p$ were statistically significant at $<0.05$.

\section{Results and discussion}

Characterization of BCP and collagen-BCP Scaffolds

The crystallinity and phase composition in pure $\mathrm{BCP}$ and collagen-BCP scaffolds were investigated by using XRD. X-ray diffraction patterns of pure BCP and collagen-BCP scaffolds are consisted of two phases (HA and $\beta$-TCP) and is shown in Fig. 1. The ratio of HA and $\beta$-TCP phases calculated by Rietveld method in both BCP scaffolds was $60 / 40$ and did not show any change of crystallinity.

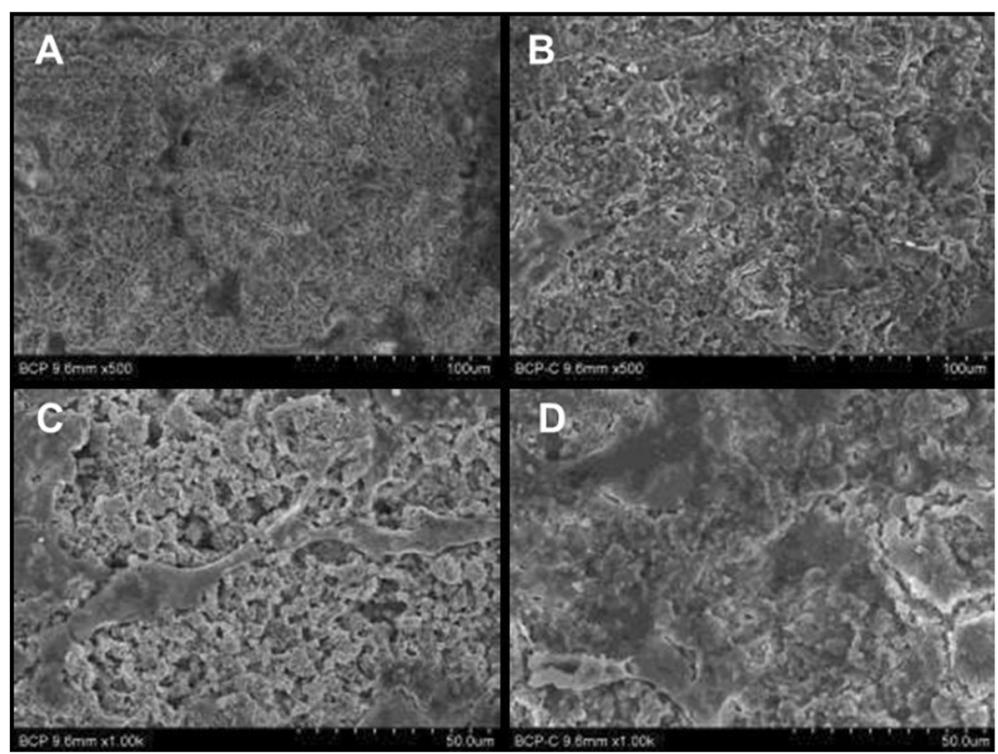

Fig. 5 Cell morphology of MC3T3-E1 on BCP scaffolds and collagen/BCP scaffolds. SEM images of MC3T3-E1 cultured on BCP scaffolds (a, c) and collagen-BCP scaffolds (b, d) for $24 \mathrm{~h}$ at magnifications of $\times 500(\mathbf{a}, \mathbf{b})$ and $\times 10000(\mathbf{c}, \mathbf{d})$ 

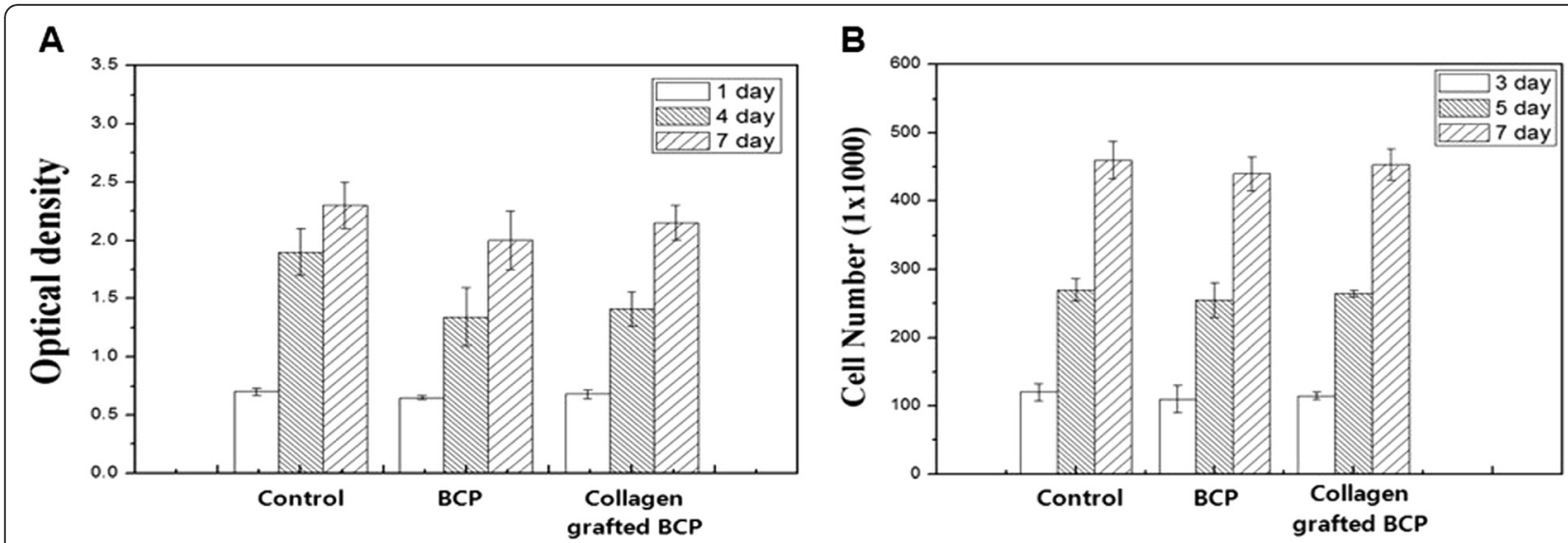

Fig. 6 Cell proliferation of MC3T3-E1 cultured on BCP scaffolds and collagen/ BCP scaffolds. Proliferation of MC3T3-E1 cells were determined by MTT assay (a) and cell counting (b). Data are expressed as the mean $\pm S D(n=3)$

The surface topography in both $\mathrm{BCP}$ and collagenBCP scaffolds was observed by using SEM (Fig. 2). SEM images show submicron-sized grains with interconnected micropore structures in the $\mathrm{BCP}$ and collagen$\mathrm{BCP}$ scaffold. The collagen-BCP scaffold had a similar surface morphology to the BCP scaffold at low magnification images but showed the collagen on the surface at higher magnifications.

In order to confirm the collagen grafting, XPS analysis was conducted (Fig. 3). The $\mathrm{N}_{1 \mathrm{~s}}$ (nitrogen peak) on the collagen-BCP scaffold was observed in the XPS pattern (Fig. 3-b). An observation of $\mathrm{N}_{1 \mathrm{~s}}$ signal in the XPS pattern means the presence of amino group of collagen and the crosslinking of collagen on BCP scaffolds.

The presence of collagen on collagen-BCP scaffold was also observed by using Coomassie brilliant blue staining (Fig. 4). Coomassie brilliant blue staining is generally used for detection of protein on sodium dodecyl sulfate polyacrylamide gel electrophoresis (SDS-PAGE) and widely used in a various area. The color of BCP scaffolds is purple if the collagen is present on the surface. The Coomassie brilliant blue is binding with collagen. This method has an advantage that the presence of collagen on specimen can distinguish with the naked eye without using equipment such as SEM and XPS etc. The purple color on collagen-BCP scaffold was observed on all surfaces.

Therefore, it is demonstrated that the collagen was crosslinked efficiently on BCP scaffolds using EDC/ NHS method and the crosslinking of collagen did not affect overall structure of scaffolds.

\section{Behaviors of osteoblastic cells on collagen-BCP Scaffold}

To evaluate the effects of collagen on cell attachment, MC3T3-E1 cells were cultured on the BCP scaffold and the collagen-BCP scaffold for $24 \mathrm{~h}$, and then the cell morphology was observed by using SEM. The cells on the collagen-BCP scaffold were more spread compared with the cells on the BCP scaffold (Fig. 5). This result coincides with the result of previous study. The cells on collagen grafted HA were more spread than those on pure HA [25]. Therefore, it is demonstrated that the collagen in BCP scaffold enhanced the cell attachment ability in early phase.

After incubation for 1, 4, 7 days, the cell proliferation in control, pure BCP and collagen-BCP scaffolds was

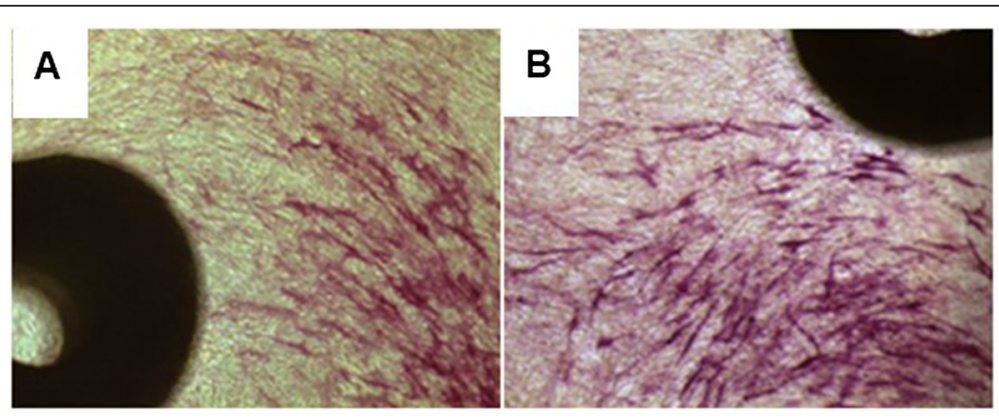

Fig. 7 ALP staining of differentiating MC3T3-E1 cultured on BCP scaffolds and collagen/BCP scaffolds. MC3T3-E1 cells were cultured in osteogenic media, and then ALP staining was performed. ALP staining image of BCP scaffolds (a) and collagen/BCP scaffolds (b) 
analyzed by MTT assay. The cell counting in mouse osteoblastic cells (MC3T3-E1 cells) for cultured samples was conducted in terms of incubation periods $(3,5$, 7 days). The collagen- $\mathrm{BCP}$ scaffold showed similar absorbance and cell number with that of cells on the $\mathrm{BCP}$ scaffold for the incubation time (Fig. 6). There was no statistical difference in cell proliferation between the collagen-BCP and pure BCP scaffold $(P>0.1)$.

To evaluate the effects of collagen on osteoblastic differentiation, MC3T3-E1 cells were cultured in osteogenic media, and then ALP staining was performed (Fig. 7). ALP-positive cells on the collagen-BCP scaffold were increased compared with the cells on the pure $\mathrm{BCP}$ scaffold. ALP positive cells are shown in red. Even exogenous type I collagen facilitated osteogenic differentiation and acts as a substrate for mineralization [18].

It is believed that the collagen in BCP scaffold enhanced the cell attachment ability in early phase and osteoblastic differentiation. That is, collagen which is bone extracelluar matrix protein may play a critical role in osteoblastic differentiation and phenotypic expression.

\section{Conclusions}

BCP scaffolds were HA/ $\beta$-TCP phase ratio of $60 / 40$ and had porous microstructure with submicron-sized grains. The collagen was successfully crosslinked into the BCP scaffolds by the EDC/NHS crosslinking method. The cell proliferation of collagen-BCP scaffolds showed a similar pattern to those of the BCP scaffolds. However, cell attachment and osteolbastic differentiation were improved in the collagen-BCP scaffolds. The collagen in the collagen-BCP scaffold was effective in osteoblastic differentiation and phenotypic expression. These results indicate that the collagen-BCP scaffolds with interconnected micropore structures is a good candidate as an osteoconductive bone substitute for the repair of bone defects.

\section{Availability of supporting data}

There was no available supporting data.

\section{Competing interests}

The authors declare that they have no competing interests.

\section{Authors' contributions}

DJY designed the experiments. JHJ and HWA carried out characterizations of BCP fabricated by precipitation method. KOP participated in the crosslinking of collagen and in vitro assays. SYL drafted the manuscript and helped to interpret data. KBP and SYK participated in its design and coordination and helped to draft the manuscript. All authors read and approved the final manuscript.

\section{Acknowledgements}

This work was supported by the Yeungnam University and and Dae-Gyeong Leading Industry Office through the Leading Industry Development for Economic Region.

\section{Author details}

'Department of Institute of Science \& Technology, Megagen Implant, Jain-myeon, Gyeongsan, Gyeongbuk 712-852, Korea. ${ }^{2}$ School of Materials Science \& Engineering, Yeungnam University, Gyeongsan, Gyeongbuk 712-749, Korea.

Received: 24 September 2015 Accepted: 4 January 2016

Published online: 15 January 2016

\section{References}

1. Moskow BS, Lubarr A. Histological assessment of human periodontal defect after durapatite ceramic implant. Report of a case J Periodontol. 1983;54:455-62.

2. Kenney EB, Lekovic V, Han T, Carranza Jr FA, Dimitrijevic B. The use of a porous hydroxyapatite implant in periodontal defects. I. Clinical results after six months. J Periodontol. 1985;56:82-8.

3. Yukna RA, Yukna CN. A 5-year followup of 16 patients treated with coralline calcium carbonate (Biocoral) bone replacement grafts in infrabony defects. J Clin Periodontol. 1998;25:1036-40.

4. Zerbo IR, Zijderveld SA, De Boer A, Bronckers AL, De Lange G, Ten Bruggenkate CM, et al. Histomorphometry of human sinus floor augmentation using a porous beta-tricalcium phosphate: a prospective study. Clinical Oral Implants Research. 2004;15:724-32.

5. Simion M, Fontana F, Rasperini G, Miorana C. Vertical ridge augmentation by expanded-polytetrafluoroethylene membrane and a combination of intraoral autogenous bone graft and deproteinized anorganic bovine bone (Bio-Oss). Clinical Oral Implants Research. 2007;18:620-9.

6. Lu J, Descamps M, Dejou J, Koubi G, Hardouin P, Lemaitre J, et al. The biodegradation mechanism of calcium phosphate biomaterials in bone. J Biomed Mater Res. 2002;63:408-12.

7. LeGeros RZ, Lin S, Rohanizadeh R, Mijares D, LeGeros JP. Biphasic calcium phosphate bioceramics: preparation, properties and applications. J Mater Sci Mater Med. 2003;14:201-9.

8. Hulbert SF, Young FA, Mathews RS, Klawitter JJ, Talbert CD, Stelling FH. Potential of ceramic materials as permanently implantable skeletal prostheses. J Biomed Mater Res. 1970;4:433-56.

9. Tsuruga E, Takita H, Itoh H, Wakisaka Y, Kuboki Y. Pore size of porous hydroxyapatite as the cell-substratum controls BMP-induced osteogenesis. J Biochem. 1997:121:317-24.

10. Gauthier O, Bouler JM, Aguado E, Pilet P, Daculsi G. Macroporous biphasic calcium phosphate ceramics: influence of macropore diameter and macroporosity percentage on bone ingrowth. Biomaterials. 1998;19:133-9.

11. Kuboki Y, Jin Q, Kikuchi M, Mamood J, Takita H. Geometry of artificial ECM: sizes of pores controlling phenotype expression in BMP-induced osteogenesis and chondrogenesis. Connect Tissue Res. 2002;43:529-34.

12. Lecomte A, Gautier H, Bouler JM, Gouyette A, Pegon Y, Daculsi G, et al. Biphasic calcium phosphate: a comparative study of interconnected porosity in two ceramics. J Biomed Mater Res B Appl Biomater. 2008;84:1-6.

13. Walsh WR, Vizesi F, Michael D, Auld J, Langdown A, Oliver R, et al. Beta-TCP bone graft substitutes in a bilateral rabbit tibial defect model. Biomaterials. 2008;29:266-71.

14. Park JW, Kim ES, Jang JH, Suh JY, Park KB, Hanawa T. Healing of rabbit calvarial bone defects using biphasic calcium phosphate ceramics made of submicron-sized grains with a hierarchical pore structure. Clin Oral Impl Res. 2010;21:268-76.

15. Andrianarivo AG, Robinson JA, Mann KG, Tracy RP. Growth on type I collagen promotes expression of the osteoblastic phenotype in human osteosarcoma MG-63 cells. J Cell Physiol. 1992;153:256-65.

16. Lynch MP, Stein JL, Stein GS, Lian JB. The influence of type I collagen on the development and maintenance of the osteoblast phenotype in primary and passaged rat calvarial osteoblasts: modification of expression of genes supporting cell growth, adhesion, and extracellular matrix mineralization. Exp Cell Res. 1995:216:35-45.

17. Mizuno M, Fujisawa R, Kuboki Y. Type I collagen-induced osteoblastic differentiation of bone-marrow cells mediated by collagenalpha2beta1 integrin interaction. J Cell Physiol. 2000;184:207-13.

18. Kihara T, Hirose M, Oshima A, Ohgushi H. Exogenous type I collagen facilitates osteogenic differentiation and acts as a substrate for mineralization of rat marrow mesenchymal stem cells in vitro. Biochem Biophys Res Commun. 2006;341:1029-35. 
19. Teixeira S, Fernandes MH, Ferraz MP, Monteiro FJ. Proliferation and mineralization of bone marrow cells cultured on macroporous hydroxyapatite scaffolds functionalized with collagen type I for bone tissue regeneration. J Biomed Mater Res A. 2010;95:1-8.

20. Brkovic BM, Prasad HS, Rohrer MD, Konandreas G, Agrogiannis G, Antunovic $D$, et al. Beta-tricalcium phosphate/type I collagen cones with or without a barrier membrane in human extraction socket healing: clinical, histologic, histomorphometric, and immunohistochemical evaluation. Clin Oral Investig. 2012;16:581-90.

21. Wissink MJ, Beernink R, Pieper JS, Poot AA, Engbers GH, Beugeling T, et al. Immobilization of heparin to EDC/NHS-crosslinked collagen.

Characterization and in vitro evaluation. Biomaterials. 2001;22:151-63.

22. Wissink MJ, Beernink R, Poot AA, Engbers GH, Beugeling T, Van Aken WG, et al. Improved endothelialization of vascular grafts by local release of growth factor from heparinized collagen matrices. J Control Release. 2000;64:103-14.

23. Wissink MJ, Beernink R, Scharenborg NM, Poot AA, Engbers GHM, Beugeling $T$, et al. Endothelial cell seeding of (heparinized) collagen matrices: effects of bFGF pre-loading on proliferation (after low density seeding) and procoagulant factors. J Control Release. 2000;67:141-55.

24. van den Dolder J, Vehof JW, Spauwen PH, Jansen JA. Bone formation by rat bone marrow cells cultured on titanium fiber mesh: Effect of in vitro culture time. J Biomed Mater Res. 2002:62:350-8.

25. Lee DW, Lee EJ, Chum SS, Ahn MW, Song IW, Kang IK, et al. Characterization of bone cell behaviors on collagen grafted hydroxyapatite surfaces. Key Eng Mater. 2008;361-363:1143-6.

\section{Submit your next manuscript to BioMed Central and we will help you at every step:}

- We accept pre-submission inquiries

- Our selector tool helps you to find the most relevant journal

- We provide round the clock customer support

- Convenient online submission

- Thorough peer review

- Inclusion in PubMed and all major indexing services

- Maximum visibility for your research

Submit your manuscript at www.biomedcentral.com/submit

C Biomed Central 